\title{
Skilled Unemployment and Creation of Academic Spin-Offs: A Recession-push Hypothesis
}

\begin{abstract}
Push factors associated with necessity entrepreneurship are largely neglected in academic entrepreneurship literature. We link research on technology transfer to literature on opportunity and necessity entrepreneurship, by showing that the rate of creation of academic spin-offs is higher when skilled unemployment rate is higher. With a longitudinal study of 559 spin-offs launched in the period 1999 to 2013 and controlling for several university- and context-level factors, we find that, while a higher level of unemployment lowers the probability to create an academic spinoff until up to a threshold, which reverses the effects. By contrast, the relative level of skilled unemployment is positively related to the probability to create academic spinoffs, in particular hitech spinoffs. Further, the relationship between the level of skilled unemployment and the creation of hi-tech spinoffs is positively moderated by the university research orientation and by the regional research and human capital intensity.
\end{abstract}

Keywords: Academic entrepreneurship; Academic Spin-offs; Unemployment; Skilled Unemployment; Young Unemployment. 


\section{Introduction}

The relationship between unemployment and self-employment has been studied extensively, and has been recognized to have a complex and multi-faceted nature (Congregado et al., 2012; Thurik et al., 2008). Yet, the relation between unemployment and academic spin-off creation has remained understudied. This is somewhat surprising when it is known that, from a purely professional perspective, the creation of academic spin-offs can be perceived as a form to reduce unemployment, particularly skilled unemployment (Bekkers et al., 2006). Since literature focusing on the relation between unemployment and academic spin-off creation is non-existent, to the best of our knowledge, this article bases its analysis on the literature that relates unemployment with entrepreneurship.

We argue that the 'recession-push' hypothesis has an impact in the creation of academic spin-offs, the same way it has on the creation of self-employment in a broader sense. The 'recession-push' hypothesis states that in periods of high unemployment there are surges of entrepreneurship, because individuals are pushed to create their own firms as an alternative strategy to paid employment (Román et al., 2013). Congregado et al. (2012) further adds to this hypothesis by finding that this relation is non-linear. In this paper, we apply these arguments to test whether the rate of creation of academic spin-offs is related to unemployment rates.

Unemployment rates are strongly associated to economic cycles, and so are youth unemployment rates that have increased and, to a large extent, maintained constant in several countries, particularly those most affected by the 2008 financial crisis (Choudhry et al., 2012). This youth unemployment considers skilled unemployment, which has also been rising in some countries, leading some scholars to argue for the role of education and public policies, and concerns about brain-drain, placing this topic at the center of policy agendas (Guardiola and Guillen-Royo, 2015). At the same time, the "Survey of Doctorate Recipients" shows that the number of students willing to become faculty members is larger than the number of those who will actually find employment in that sector, suggesting imbalances in the scientific labor market (Roach and Sauermann, 2010).

Moreover, while the number of tertiary education students is increasing, in many countries public support to universities is decreasing and it is evolving towards the improvement of the efficiency of research organization rather than increasing research expenditures (Mangematin, 2000). Under these conditions, an entrepreneurial career, through the foundation of an academic spin-off, can allow a skilled individual a satisfactory exploitation of advanced knowledge in a certain field of expertise. Therefore, in some cases the spin-off may not be the first-best solution, but rather a compensatory, self-employment opportunity, in which young researchers engage in the absence of jobs. If this is the case, we expect that, at a regional level, when the job opportunities decrease, compared to the number of fresh graduates, the propensity to spin-off increases.

A number of studies emphasize the impact of individual attributes and dispositions on academic entrepreneurship, highlighting how the motivations that induce researchers to create new ventures are wider than in other contexts and not driven solely by an entrepreneurial vision. For example, they may be attracted by the prospect of enhancing their position (Meyer, 2003), or be motivated by a need for achievement (Roberts, 1991), or a desire of independence and challenge (Hessels et al. 2008). Other individual motives include seek 
of recognition by peers and ambition to develop a technology into a marketable product (Hayter, 2011). The set of personal motivations proposed by the literature is thus diversified. Spanning from monetary rewards to self-enhancing goals, these are, however, all 'positive' motivations. One exception is the recent paper by Rizzo (2014), whose case studies show that sometimes the creation of academic spin-offs in an Italian region offer young scholars a way to escape the bottlenecks of the Italian academic system allowing them to work in their field of expertise.

This study broadens these perspectives and explicitly investigate the relationship between unemployment, in particular skilled unemployment, and the creation of academic spin-offs, in particular hi-tech spin-offs. With a longitudinal study of 559 spin-offs launched from 85 universities in the period 1999 to 2013, we test whether the rate of establishment of spin-offs (number of spin-offs per year per university) is related to unemployment rates. Controlling for several university- and context-level factors, we find support for our hypotheses. While a higher level of unemployment lowers the probability to create an academic spinoff until up to a threshold, which reverses the effects, the relative level of skilled unemployment is positively related to the probability to create academic spinoffs, in particular hi-tech spinoffs. Further, the relationship between the level of skilled unemployment and the creation of hi-tech spinoffs is positively moderated by the university research orientation and by the regional research and human capital intensity.

The remainder of the article is organized as follows. Section 2 reviews the related literature and develops the hypotheses of the paper. Section 3 describes the research design. Section 4 presents the results, and Section 5 concludes the paper.

\section{Literature review and hypotheses}

The relation between unemployment and the creation of self-employment has warranted mixed results (Thurik et al., 2008). These are themselves aligned with the ambiguous predictions provided by the theory on this relationship. The theory implies a dual relation where self-employment and unemployment have a positive relation, that is, the more self-employment the lesser unemployment and vice-versa. However, due to high unemployment levels, the market demand on firms becomes lesser, reducing the prospects of capital availability (to start the firm) and potential income increasing the risk of starting a firm or that the created firm can bankrupt fairly quickly. The theory thus encompasses two contradictory forces: one that "pushes" unemployed individuals towards self-employment as an alternative form of income source in paid employment (difficult to find in high unemployment), while at the same time pulling individuals from self-employment due to the risks brought by the lack of market demand and purchasing power of economies where a substantial part of the population is without employment.

At this point the theory predicts a full circle, as it is argued that it is possible that in severe recession periods with extremely high levels of unemployment, and when a large number of firms is closing down, an availability of second hand capital equipment emerges and reduce barriers to firm-entry, thus leading to - once again - a positive effect between unemployment and self-employment (Binks and Jennings, 1986). In simpler terms, the theory suggest that the relation between unemployment and firm creation can either be positive or negative 
(Parker, 2009; Hamilton, 1989). Empirical studies find mixed results concerning this relation, either favoring a positive (e.g, Fritsch et al., 2014; Wang, 2006) or a negative (Torrini, 2005) relationship between unemployment and self-employment. The question thus seems to be related to the degree the unemployment rate influencing this relation. Congragado et al. (2012) for example found that in Spain for the period 19762004, the positive relationship between unemployment and self-employment only stands valid when the unemployment rate is lower than 39\%. Since the unemployment in Italy in the past 15 years has been around 9\% (see Table 3), one would assume that the higher is the level of unemployment at the regional level, the lower will be the probability for academic spinoffs to be created.

We highlight the regional level for two reasons: to ascertain if the entrepreneurial cycles that are positively affected by national unemployment cycles (Faria, 2014; Koellinger and Thurik, 2012) are also valid at regional level, and to take into account the relevance of regional characteristics affecting the formation of academic spin-offs, knowing from the literature that issues of proximity to the university impact positively the formation of academic spin-offs (Baptista et al., 2011) and that regional unemployment also impacts firm formation (Aubry et al., 2014). A further recent analysis found that in the US, local market conditions can be major determinants of entrepreneurship and that those initially not employed - which one can assume as typical academic spin-off entrepreneurs - are more likely than employed individuals to start a business in face of unfavorable localized market conditions (Fairlie, 2013). However, since the relation between unemployment and academic spin-off formation is expected to be non-linear, a statement needs to be added to our hypothesis, following Hamilton's (1989) conceptual suggestion of reversing effects between unemployment and firm creation when a given unemployment level threshold has been reached, whereas:

H1: The level of unemployment at the regional level lowers the probability to create an academic spinoff until a determined threshold, which reverses the effect (from recession push to prosperity pull)

The analyses of unemployment levels (associated with either periods of economic growth and recession) and its relation to self-employment refer not only to entrepreneurship trends but also to unemployment in general. However, university graduates and students when engaged in self-employment are expected to assume unemployment levels under the perspective of market demand and risk. This is arguably so, because as long as students graduate from tertiary education, they will always be skilled human capital, and the literature suggests that skilled unemployment differs from unskilled in terms of employment (Stier, 2015) and unemployment (Gesthuizen et al., 2011).

Skilled individuals are also found to be more resilient to unemployment cycles and investment in education continues to be perceived as one of the surest instruments to obtain higher wages and find employment (Cardoso and Ferreira, 2009). Skilled individuals are less prone to experiencing job insecurity, low status jobs, lower wage premiums and unemployment when compared to less skilled individuals (Gesthuizen et al., 2011). The literature and empirical findings show that the skills that skilled individuals possess are aligned with future needs of the knowledge economies - total employment is still highest for these individuals - dismissing to a 
large extent arguments of over-education of the labor force even as unemployment rates rise (Cardoso and Ferreira, 2009; Spitz-Oener, 2006). These findings suggest that skilled unemployment levels and general unemployment levels are different. Moreover, since the entrepreneurs of the academic spin-offs are all educationally speaking, qualified, it is reasonable to assume that skilled unemployment is probably more important than local unemployment to decide on self-employment, although local unemployment rates should be considered (in terms of consumer market and market demand). This leads to forwarding the following hypothesis:

H2: The higher is the relative level of skilled unemployment at the regional level, the higher will be the probability to create academic spinoffs

The assumption that skilled vs general unemployment may be different in affecting the greater or lesser propensity for individuals to opt for self-employment through the creation of academic spin-offs would be incomplete if only tested in the hypothesis above. This is so because academic spin-offs tend to rely on university support while transferring to industry the results of publicly funded research, and often are originated around research outcomes of university sponsored projects (Festel, 2013; Clarysse et al., 2005). Even if the processes leading to their creation can be described as heterogeneous (Mustar et al., 2006), and academic spin-offs differ in their nature according to the proximity levels to the university and sponsoring sources (Bathelt et al., 2010), they tend to be associated with fostering high-technology industries (Steffensen et al., 2000). This leads to forward the following ancillary hypothesis:

H2a: The higher is the level of skilled unemployment at the regional level, the higher will be the probability to create hi-tech spinoffs (rather than low-tech spin-offs)

The relations between firm performance, size and productivity are highly associated to structural factors related to the economic organization of countries and regions (Calcagnini and Favaretto, 2011). Several articles in the literature highlight the role of holistic conditions in fostering the creation of academic spin-offs, particularly high technology spin-offs (Gilsing et al., 2010; Bekkers et al., 2006). In this context, it is underlined the relevance that regional context and characteristics have, which were found to be of greater importance than public policies oriented towards entrepreneurship (Sternberg, 2014), but also the characteristics of the universities in their role to foster entrepreneurial attitudes and how these can contribute to the social and economic development of regions and countries alike (see Patton and Kenney, 2010; Braunerhjelm, 2008). Still, the literature evidences that the role of universities in supporting academic spin-off creation is strongly associated to their greater or lesser research orientation and the research and development expenditures given to them and to the region where they are located (Lee et al., 2004; Feldman, 2000). Recent research focused on the Italian region of Emilia-Romagna also suggest that these contextual characteristics are key in shaping individual motivations towards self-employment (Rizzo, 2014). However, there is no study in the literature 
showing how the relation between skilled employment and academic spin-offs are moderated by contextual dimensions at institutional (i.e, university) and systemic levels (i.e, regional characteristics). This is important to be assessed when it is known that regional and institutional characteristics influence unemployment dynamics and how unemployment impacts development (e.g, Stolarick and Currid-Halkett, 2013). Based on these arguments, the two following hypotheses are forwarded:

H3: The relationship between the level of skilled unemployment and the creation of hi-tech spinoffs is positively moderated by the university research orientation

H4: The relationship between the level of skilled unemployment and the creation of hi-tech spinoffs is positively moderated by the regional research and human capital intensity

\section{Methodology and Data}

\subsection{Sample}

In our analysis, the sample is made of spin-offs from Italian universities, established from 1999 to 2013. We started from 1999 because of the introduction of a new dedicated regulatory framework focused on supporting scientific and technological research, knowledge transfer, and researchers' mobility (Law 297/1999 and Ministerial Decree 593/2000). Since then, public researchers can be involved in technology-transfer projects while keeping their university position and wage. Using data from the Italian Ministry of Education, University and Research (MIUR), we identify 85 universities to be considered in our analysis ${ }^{1}$. Our dataset is built using information available from the websites of the universities, where TTOs report the list of affiliated spin-offs. Overall, our sample is composed of 559 spin-offs established between 1999 and 2013 from 56 universities, out of a population of 85 universities.

Academic spin-offs are firms either created by faculty, tertiary education students, graduates or both. With respect to this characterization, two factors needs to be considered in the light of recent evidence (see Astebro et al., 2012). First, this representation realistically depicts the variety of of academic spin-offs that are created in university-based contexts (while at the same time considering academic entrepreneurship using broader definitions to better grasp the influence of context upon it as a social phenomenon; see Link et al., 2007). Second, academic spin-offs created by graduates (including those with undergraduate degrees) are found to be larger than the ones created by faculty while with similar levels of quality. This variety therefore allows to highlight a key feature: in periods of unemployment, the ones more interested in obtaining employment in present and near future time periods are the tertiary education students and graduates, and not so much the faculty (which are already employed at the university).

\footnotetext{
${ }^{1}$ From the full population of 96 institutions, we dropped 11 long-distance only universities. None of them was involved in spin-off transactions over the period considered by our analysis.
} 
Spin-offs in our sample are classified as hi-tech spin-offs if they are firms in high- and medium-high technology sectors according to the OECD classification (OECD Science and Technology Scoreboard). Namely, firms in Aerospace, Computers, Electronics-communications, Pharmaceuticals, Scientific instruments, Motorvehicles, Machinery, Chemical, and Transport equipment are considered as hi-tech spinoffs. All other spin-offs in our sample are classified as low-tech spin-offs.

Table 1 reports the number of spin-offs per year in our sample, distinguishing hi-tech and low-tech spin-offs. In our sample there are 416 hi-tech spin-offs and 143 low-tech spin-offs, representing $74.4 \%$ and $25.6 \%$ of the total number of spin-offs respectively. Spin-off creation has increased in Italy over the past 15 years, with most of the spin-offs being created in the period 2004-2009. By contrast, a decrease in the number of established firms is observable during the period 2010-2013, arguably due to the effects of the economic crisis. The lower panel of the table splits spin-offs according to the three Italian macro-region (North, Centre and South): as expected, the largest share of spin-offs (45.6\%) was established in Northern Italy, while Centre and South are represented by $34.9 \%$ and $19.5 \%$ of spin-offs respectively. Interestingly, while in Northern Italy the share of hi-tech spin-offs is $67.5 \%$, this percentage rises up to $79.5 \%$ in the Centre, and to $81.7 \%$ in the South.

\section{[INSERT HERE TABLE 1]}

\subsection{Model and main variables}

To perform our longitudinal study, we use panel-data negative binomial regressions, where the dependent variable is either the total number of spin-offs per university per year, or the number of hi-tech spin-offs per university per year, or the number of low-tech spin-offs per university per year. We measure the effect of our independent variables on 1,275 university-year observations ( 85 universities observed for 15 years between 1999 and 2013). Our main explanatory variables are two measures of local unemployment: regional unemployment and relative skilled unemployment. Both variables are measured at the NUTS 2 level ${ }^{2}$. Regional unemployment rate is defined as the percentage ratio of regional population aged 15 and over seeking employment to the labour force, according to the definition used by the Italian Institute for Statistics (ISTAT). In particular, the labour force is defined as the sum of people in employment and people seeking employment, while the definition of a person seeking employment refers to the concept of actively seeking work, i.e. having performed at least one job-seeking action of a given type. Our analysis aims at testing the significance of this variable in predicting the number of spin-offs per university per year, as an evidence in support of Hypothesis 1. Since the Hypothesis provides for a curvilinear impact of unemployment on spin-off creation, we will use also a quadratic term.

\footnotetext{
${ }^{2}$ The Nomenclature of Territorial Units for Statistics or Nomenclature of Units for Territorial Statistics (NUTS) is a geocode standard for referencing the subdivisions of countries for statistical purposes. The standard is developed and regulated by the European Union, and thus only covers the member states of the EU in detail. For each EU member country, a hierarchy of three NUTS levels is established by Eurostat. In the case of Italy, the NUTS 2 level refers to regions, although Trentino-Alto Adige is split into two (the autonomous provinces of Trento and Bolzano).
} 
Relative skilled unemployment is defined as the ratio between the rate of highly educated unemployment (holding either a short-cycle tertiary, bachelor or equivalent, master or equivalent, doctoral or equivalent degree) and the total rate of unemployment, at the regional level. In practice, this ratio is greater than one if the percentage of skilled unemployed is greater than the percentage of unemployment, and vice versa. Hypothesis 2 provides expectations for a significant effect of relative skilled unemployment on the creation of spin-offs. In order to test Hypothesis 2a, we will assess whether relative skilled unemployment increases the probability to create hi-tech spin-offs, rather than low-tech spin-offs.

Hypotheses 3 and 4 are tested by considering the moderating effects for the relative skilled unemployment. First, in order to test Hypothesis 3, we interact relative skilled unemployment with a measure of university research orientation, namely the faculty research productivity, measured as the number of articles published in scientific journals per faculty member. Further, in order to test Hypothesis 4, we interact relative skilled unemployment with a proxy of regional research, and a proxy of regional human capital intensity. Our proxy for regional research is the regional $R \& D$ expenditure, while our measure of human capital intensity is the variable STEM graduates, calculated as the number of graduates in science, technology, engineering and mathematics, between 20 and 29 years old, per thousand people.

\subsection{Control variables}

The choice for the control variables draws to a large extent from the work of Bekkers et al. (2006) which rests on the assumption that different institutional layers in a national scientific system affect the creation of spinoffs. This model is particularly useful because research has shown (including the one conducted by Bekkers et al., 2006, and others, Gilsing et al., 2010) that broad institutional levels provide the conditions that affect the creation of spin-offs. The adoption of this model is aligned with the purpose of this paper, which aims at better understand how unemployment in general and skilled unemployment in particular affect the establishment of spin-offs. However, the holistic view given by this model also requires to delve and integrate literature that focus on the role of national and regional characteristics in fostering firm creation and higher education institutions and associated organizations mandated to promote knowledge transfer activities, such as Technology Transfer Offices (Rasmussen et al., 2006). Bekkens et al. (2006) framework is both inclusive and coherent to include and combine antecedent institutional level conditions enabling a better understanding what leads to greater or smaller propensity to create spin offs.

This is why, in all our analyses, we make use of a set of controls classified into three groups, accounting for the specificities of the academic, regional and national context. The first category is composed by universitylevel control variables, and includes a measure of university size (number of students, including Bachelor, Master, $\mathrm{PhD}$ and specialization courses), and a measure of university patenting activity (number of patents), in addition to the measure of faculty research productivity, mentioned among the moderators. The second category groups regional level control variables: it includes the regional GDP growth, the Gini coefficient (a measure of income distribution within each region), hi-tech employment (percentage of total employment employed in hi-tech manufacturing and knowledge intensive services), and household income (mean net 
household income, after taxes and mandatory contributions), in addition to the regional R\&D expenditure and STEM graduates, listed among the moderators. The third group includes Italian level control variables ${ }^{3}$, identified as the consumer confidence index, the industry confidence index, and the service confidence index (all defined by the Eurostat), and the final consumption expenditure (expenditure incurred by resident households on individual consumption of goods and services). In addition to all controls presented above, we include a set of dummy variables related to the macro regions, to take into account of all potential unobservable differences between these areas.

Our sources of data for all control variables are the MIUR (Italian Ministry for University and Research), the CRUI (Conference of Rectors of Italian Universities) and the SCOPUS database for university data, while the data referred to the local context are collected from the ISTAT (Italian National Institute of Statistics) and the Eurostata (a Directorate-General of the European Commission providing statistical information to the institutions of the European Union). Details on the definition of the variables and their sources are reported in Table 2.

\section{[INSERT HERE TABLE 2]}

\subsection{Descriptive statistics}

Table 3 reports the descriptive statistics for the 1,275 university-year observations employed for our empirical analysis, reporting separate statistics for North, Central and South of Italy, while a correlation matrix is provided in the Appendix. On average, the level of local unemployment in Italy, over the period considered in our analysis, has been of $8.7 \%$. Indeed, the average level is much lower in the North (4.9\%), while it rises to $7.3 \%$ in the Centre and to $15.9 \%$ in the South. Viceversa, the level of relative skilled unemployment has been higher in the North (0.99) than in the South (0.93). This is mainly due to a much higher concentration of graduates in the North, then in the Southern of the country. Among the moderators, we learn from this table that faculty research productivity shows top values in the North ( 0.98 papers per faculty per year), while lower levels are observed in the Centre (0.77) and in the South (0.63). The North is also characterized by a higher regional $R \& D$ expenditure and a higher availability of STEM graduates. Italian universities enroll on average about 31,000 students, with TTOs characterized, in average, by 4.4 employees. In terms of regional characteristics, regional GDP growth has been of 0.1 on average $(0.3$ in the North, 0.4 in the Centre, and -0.3 in the South), while the Gini coefficient identifies higher inequality in the South (0.30) with respect to North $(0.28)$ and Centre $(0.27)$. Northern regions are also characterized by a higher share of hi-tech employment and by a higher level of household income with respect to the rest of the country.

\footnotetext{
${ }^{3}$ The various confidence indexes serve to control for the relation between self-employment and macroeconomic forces, which are known to influence entrepreneurial activity (see Fritsch et al., 2014). These controls can have differing impacts on firm creation. For example, self-employment can be fostered when labor and production costs are low due to high unemployment and economic recession (Francois and Lloyd-Ellis, 2003) but the literature also suggests that during high unemployment and recession periods, individuals may be less willing to create firms when econo mic prospects look bleak and the associated uncertainty makes firm creation to be overly risky (Rampini, 2004).
} 


\section{[INSERT HERE TABLE 3]}

\section{Results}

Table 4 reports the estimates of negative binomial panel regressions on the total number of spin-offs, on the number of hi-tech spin-offs and on the number of low-tech spin-offs created per year by the 85 Italian universities. In all models, we include all university- regional- and Italia context-level control variables, as well as a set of dummies to control for macro-regional effects. The impact of Local unemployment is measured through the coefficient of Local unemployment and Local unemployment ${ }^{2}$ : both coefficient are statistically significant at less than 1 percent, the first being negative $(-0.310$ for the total number of spin-offs, -0.312 for hi-tech and -0.568 for low-tech spin-offs, $\mathrm{p}<0.01$ in all cases) and the second being positive $(0.008$ for the total number of spin-offs, 0.008 for hi-tech and 0.017 for low-tech spin-offs, $\mathrm{p}<0.01$ in all cases), providing empirical support for Hypothesis 1. In practice, unemployment has a strong negative impact on spin-off creation, up to a certain threshold, which reverses the effect. Among university-context variables, faculty research productivity positively affects the creation of hi-tech spin-offs, while university and TTO sizes are significant determinants for the creation of all types of spin-offs. With respect to regional determinants, a primary role is played by regional R\&D expenditure, significant on the total number and on the number of hitech spin-offs, as well as the presence of STEM graduates, which significantly determines the creation of all types of spin-offs. The Gini coefficient is significant with a negative sign, showing how inequalities in the distribution of local income negatively influences the propensity to create spin-offs. Last, among confidence indices, consumer confidence index is positively and significantly correlated with the creation of all types of spin-offs.

\section{[INSERT HERE TABLE 4]}

In Table 5 we focus on the role of relative skilled unemployment, i.e. the ratio between skilled unemployment and total local unemployment. Again, we report the estimates of negative binomial panel regressions on the total number of spin-offs, on the number of hi-tech spin-offs and on the number of low-tech spin-offs created per year by the 85 Italian universities. The variable of interest here is Skilled unemployment, which is positive and significant with reference to the total number of spin-offs (coefficient=3.619, $p<0.01$ ), supporting Hypothesis 2. In order to test Hypothesis 2a, we look at the same coefficient, which is positive and signific ant for hi-tech spin-offs (coefficient=1.897, $\mathrm{p}<0.01$ ), while it is not significant for low-tech spin-offs. The coefficient of most control variable are very close to those reported in Table 4, at similar levels of significance. As a whole, these results support the hypothesis that the availability of skilled individuals is an important determinant for the creation of academic spin-off, but this effect is pronounced on hi-tech spin-offs, rather than on low-tech firms.

[INSERT HERE TABLE 5] 
Finally, in Table 6 we test Hypothesis 3 and 4 by including in our models the moderating effects for skilled unemployment. Our results show that the positive impact of relative skilled unemployment on the creation of spin-offs is positively moderated by faculty research productivity (coefficient $=0.210, p<0.01$ ), by regional $R \& D$ expenditure (coefficient=1.590, $p<0.10$ ), and by STEM graduates (coefficient $=0.615, p<0.05$ ). The first result is in support of Hypothesis 3, while the others are in support of Hypothesis 4. As a whole, these results suggest that the university and the regional context largely shape the relationship between relative skilled unemployment and spin-off creation. As far as universities are concerned, research-active universities determine better opportunity for spin-offs, and possibly because in this case there is much more material available to be transferred to the market. Further, the local context matters, and this is true both in terms of institutional engagement, i.e. regional $R \& D$ expenditure, and in terms of territorial human capital intensity, i.e. presence of STEM graduates.

[INSERT HERE TABLE 6]

\section{Conclusions}

Entrepreneurship literature distinguish between "push" and "pull" factors moving individuals to create a firm. Almost all the literature on academic entrepreneurship, however, is centered on a pull approach, or opportunity entrepreneurship, where incentives to the creation of firm are, directly or indirectly, driven by the desire to increase in the founder's wealth (Baumol 1990). On the contrary, push factors are associated with “necessity entrepreneurship", in which individuals are moved to create a firm in order to escape some situations of dissatisfaction (Uhlaner and Thurik 2007) are largely neglected in this stream of literature. Among such factors, unemployment is typically the most important (Storey 1991; Ritsila and Tervo 2002).

We argue that the creation of academic spin-offs is a complex process, which is stimulated by both push and pull factors. In so doing, we link research on academic entrepreneurship and technology transfer to literature on opportunity and necessity entrepreneurship. Consistently, we show that the rate of creation of academic spin-offs is higher when skilled unemployment rate is higher.

On these premises, some policy implications can be derived. We argue that the establishment of an academic spin-off can allow a doctorate holder a satisfactory exploitation of her/his advanced knowledge in a certain field of expertise. Therefore, in some cases the spin-off may not be the first-best solution, but rather a compensatory, self-employment opportunity. This carries important policy considerations. University managers find here evidence that a satisfactory spin-off activity is not necessarily related to an outstanding performance in the university "third mission", while there might be lack of opportunities for human resources, or administrative deficiencies, at the basis of such results. Relatedly, our results are relevant for policy makers. While the attention on academic spin-offs has been often motivated by the potential ability to advance scientific knowledge as well as to contribute to regional economic growth, we show how non-purely entrepreneurial motivations can be important determinants of the creation of academic spin-offs. In fact, our results are of 
interest for the stream of research highlighting the poor performance records of academic spin-offs (Bonardo et al., 2010). Ultimately, the recognition of the importance of context features can lead to the formulation of fine-tuned policies directed toward improving the weak Italian high-tech entrepreneurial awareness (Chiesa and Piccaluga 2000). 


\section{References}

Astebro, T., Bazzazian, N., Braguinsky, S., 2012. Startups by recent university graduates and their faculty: implications for university entrepreneurship policy. Research Policy 41, 663-677.

Aubry, M., Bonnet, J., Renou-Maissant, P., 2014. Entrepreneurship and the business cycle: the "Shumpeter" effect versus the "refugee" effect - a French appraisal based on regional data. Annals of Regional Science, doi: 10.1007/s00168-014-0645-x

Baptista, R., Lima, F., Mendonça, J., 2011. Establishment of higher education institutions and new firm entry. Research Policy 40, 751-760.

Bathelt, H., Kogler, D.F., Munro, A.K., 2010. A knowledge-based typology of university spin-offs in the context of regional economic development. Technovation 30, 519-532.

Baumol, W.J., 1990. Entrepreneurship: Productive, unproductive, and destructive. Journal of Political Economy 98, 893-921.

Bekkers, R., Gilsing, V., Steen, M. van der, 2006. Determining factors of the effectiveness of IP-based spinoffs: comparing the Netherlands and the US. Journal of Technology Transfer 31, 545-566.

Binks, M., Jennings, A., 1986. Small firms as a source of economic rejuvenation. In Curran, J., Stanworth, J., Watkins, D., (Eds), The survival of the small firm (pp. 19-37). Aldershot: Gower.

Bonardo, D., Paleari, S., Vismara, S., 2010. The M\&A dynamics of European Science Based Entrepreneurial Firms. Journal of Technology Transfer 35(1), 141-180.

Braunerhjelm, P., 2008. Specialization of regions and universities: the new versus the old. Industrial Innovation 15, 253-275.

Calcagnini, G., Favaretto, I., 2011. The Italian Small- and Medium-Sized Firms in the Aftermath of the Crisis. In Calcagnini, G., Favaretto, I., (Eds), The Economics of Small Businesses: An International Perspective (87-112). Heidelberg: Springer.

Chiesa, V., Piccaluga, A., 2000). Exploitation and diffusion of public research: The case of academic spin-off companies in Italy. $R \& D$ Management 30, 329-339.

Clarysse, B., Wright, M., Lockett, A., van de Velde, E., Vohora, A., 2005. Spinning out new ventures: a typology of incubation strategies from European research institutions. Journal of Business Venturing 20(2), 183-216.

Congregado, E., Golpe, A., van Stel, A., 2012. The 'recession-push' hypothesis reconsidered”. International Entrepreneurship Management Journal 8, 325-342.

Choudhry, M.T., Marelli, E., Signorelli, M. 2012. Youth unemployment rate and impact of financial crises. International Journal of Manpower, 33(1), 76 - 95

Fairlie, R.W., 2013. Entrepreneurship, economic conditions, and the great recession. Journal of Economics and Management Strategy 22, 2, 207-231.

Faria, J.R., 2014. Entrepreneurship and business cycles: technological innovations and unemployment. International Entrepreneurship Management Journal, doi: 10.1007/s11365-014-0327-2 
Feldman, M.P., 2000. Location and innovation: the new economic geography of innovation. In Clark, G., Feldman, M.P., Gertler, M. (Eds.), Oxford Handbook of Economic Geography (pp. 373-394). Oxford: Oxford University Press.

Festel, G., 2013. Academic spin-offs, corporate spin-outs and company internal start-ups as technology transfer approach. Journal of Technology Transfer 38, 454-470.

Francois, P., Lloyd-Ellis, H., 2003. Animal spirits through creative destruction. American Economic Review 93, 530-550.

Fritsch, M., Kritikos, A., Pijnenburg, K., 2014. Business cycles, unemployment and entrepreneurial entry evidence from Germany. International Entrepreneurial Management Journal, doi: 10.1007/s11365-0140326-3.

Gesthuizen, M., Solga, H., Kunster, R., 2011. Context matters: economic marginalisation of low-educated workers in cross-national perspective. European Sociological Review 2(2), 264-280.

Gilsing, V.A., Elco van Burg, A., Romme, G.L., 2010. Policy principles for the creation and success of corporate and academic spin-offs. Technovation 30, 12-23.

Guardiola, J., Guillen-Royo, M., 2015. Income, unemployment, higher education and wellbeing in times of economic crisis: evidence from Granada (Spain). Social Indicators Research, 120(2), 395-409.Hamilton, R.T., 1989. Unemployment and business formation rates: reconciling time series and cross-section evidence. Environment and Planning A 21(2), 249-255.

Hayter, C.S., 2011. In search of the profit-maximizing actor: motivations and definitions of success from nascent academic entrepreneurs. Journal of Technology Transfer 36, 340-352.

Hessels, J., Van Gelderen, M., Thurik, R., 2008. Entrepreneurial aspirations, motivations, and their drivers. Small Business Economics 31, 323-339.

Koellinger, P.D., Thurik, A.R., 2012. Entrepreneurship and the business cycle. Review of Economics and Statistics 94, 1143-1156.

Lee, S., Florida, R., Acs, Z., 2004. Creativity and entrepreneurship: a regional analysis of new firm formation. Regional Studies 38, 879-891.

Link, A., Siegel, D., Bozeman, B. 2007, An empirical analysis of the propensity of academics to engage in informal university technology transfer. Industrial and Corporate Change, 16(4), 641-655.

Mangematin, V., 2000. PhD job market: professional trajectories and incentives during the PhD. Research Policy 29(6), 741-756.

Meyer, M., 2003. Academic entrepreneurs or entrepreneurial academics? Research-based ventures and public support mechanism. R\&D Management 33, 107-115.

Parker, S., 2009. The economics of entrepreneurship. Cambridge: Cambridge University Press.

Patton, D., Kenney, M., 2010. The role of the university in the genesis and evolution of research based clusters.

In Fornahl, D., Henn, S., Menzel, M.-P. (Eds), Emerging Clusters (pp. 239-264). Cheltenham: Edward Elgar. 
Rampini, A., 2004. Entrepreneurial activity, risk, and the business cycle. Journal of Monetary Economics 51, 555-573.

Rasmussen, E., Moen, Ø., Gulbrandsen, M., 2006. Initiatives to promote commercialization of university knowledge. Technovation 26, 4, 518-533.

Ritsila, J., Tervo, H., 2002. Effects of unemployment on new firm formation: Micro-level panel data evidence from Finland. Small Business Economics 19, 31-40.

Rizzo, U., 2014. Why do scientists create academic spin-offs? The influence of context. Journal of Technology Transfer, doi: 10.1007/s10961-014-9334-2.

Roach, M., Sauermann, H., 2010. A taste for science? PhD scientists' academic orientation and self-selection into research careers in industry. Research Policy 39, 422-434.

Roberts, E.B., 1991. The technological base of the new enterprise. Research Policy 20(4), 283-297.

Román, C., Congregado, E., Millán, J.M., 2013. Start-up incentives: entrepreneurship policy or active labour market programme? Journal of Business Venturing 28, 151-175.

Spitz-Oener, A., 2006. Technical changes, job tasks, and rising educational demands: looking outside the wage structure. Journal of Labor Economics 24, 2, 235-270.

Steffensen, M., Rogers, E., Speakman, K., 2000. Spin-offs from research centers at a research university. Journal of Business Venturing 15(1), 93-111.

Sternberg, R., 2014. Success factors of university spin-offs: regional government support program versus regional environment. Technovation 34, 137-148.

Stier, H., 2015. The skill-divide in job quality: a cross-national analysis of 28 countries. Social Science Research 49, 70-80.

Stolarick, K., Currid-Halkett, E., 2013. Creativity and the crisis: the impact of creative workers on regional unemployment. Cities 33, 5-14.

Storey, D.J., 1991. The birth of new firms - does unemployment matter? A review of the evidence. Small Business Economics 3, 167-178.

Thurik, A.R., Carree, M.A., van Stel, A.J., Audretsch, D.B., 2008. Does self-employment reduce unemployment? Journal of Business Venturing 23, 6, 673-686.

Torrini, R., 2005. Cross-country differences in self-employment rates: the role of institutions. Labour Economics 12, 661-683.

Uhlaner, L., Thurik, R., 2007. Postmaterialism influencing total entrepreneurial activity across nations. Journal of Evolutionary Economics 17, 161-185.

Wang, S., 2006. Determinants of new firm formation in Taiwan. Small Business Economics 27, 313-321. 
Table 1. Sample. This table reports the number of academic spin-offs founded in Italy from 1999 to 2013. Hitech spin-offs are firms in high- and medium-high technology sectors according to the OECD classification. Low-tech spin-offs are all the others.

\begin{tabular}{ccccccc} 
& Spin-offs & \multicolumn{3}{c}{ Hi-tech } & \multicolumn{2}{c}{ Low-tech } \\
\hline Year & No. & $\%$ & No. & $\%$ & No. & $\%$ \\
\hline 1999 & 15 & 2.7 & 13 & 86.7 & 2 & 13.33 \\
2000 & 9 & 1.6 & 8 & 88.9 & 1 & 11.11 \\
2001 & 7 & 1.3 & 6 & 85.7 & 1 & 14.29 \\
2002 & 7 & 1.3 & 5 & 71.4 & 2 & 28.57 \\
2003 & 31 & 5.5 & 23 & 74.2 & 8 & 25.81 \\
2004 & 50 & 8.9 & 36 & 72.0 & 14 & 28.00 \\
2005 & 43 & 7.7 & 34 & 79.1 & 9 & 20.93 \\
2006 & 46 & 8.2 & 31 & 67.4 & 15 & 32.61 \\
2007 & 78 & 14.0 & 54 & 69.2 & 24 & 30.77 \\
2008 & 71 & 12.7 & 55 & 77.5 & 16 & 22.54 \\
2009 & 57 & 10.2 & 43 & 75.4 & 14 & 24.56 \\
2010 & 38 & 6.8 & 32 & 84.2 & 6 & 15.79 \\
2011 & 40 & 7.2 & 28 & 70.0 & 12 & 30.00 \\
2012 & 41 & 7.3 & 29 & 70.7 & 12 & 29.27 \\
2013 & 26 & 4.7 & 19 & 73.1 & 7 & 26.92 \\
\hline Region & & 0.0 & & & & \\
\hline North & 255 & 45.6 & 172 & 67.5 & 83 & 32.55 \\
Centre & 195 & 34.9 & 155 & 79.5 & 40 & 20.51 \\
South & 109 & 19.5 & 89 & 81.7 & 20 & 18.35 \\
\hline Total & 559 & 100.0 & 416 & 74.4 & 143 & 25.58 \\
\hline
\end{tabular}


Table 2. Variable Definition. ISTAT is the Italian National Statistical Institute; SCOPUS is an abstract and ; MIUR is the Italian Ministry of Research and Education; CRUI is the Conference of the Rectors of Italian Universities; EUROSTAT is a Directorate-General of the European Commission providing statistical information to the institutions of the European Union.

Variable Definition Source

Unemployment variables

Regional unemployment

The unemployment rate is given by the percentage ratio of the population aged 15 and over seeking employment to the labour force. The latter is given by the sum of people in employment and people seeking employment. The definition of a person seeking employment refers to the concept of actively seeking work, i.e. having performed at least one job-seeking action of a given type in the four weeks preceding the one to which the information gathered during the interview refers and being available to work in the two weeks that follow. The rate is calculated per year per region.

Ratio between the rate of highly educated unemployment (holding either a short-cycle tertiary, bachelor or

Relative skilled unemployment equivalent, master or equivalent, doctoral or equivalent ISTAT degree) and the total rate of unemployment. The ratio is calculated per year per region.

\section{Moderating variables \\ Faculty research productivity}

Regional R\&D Expenditure

STEM graduates
The number of articles published in scientific journals per SCOPUS, faculty member. MIUR

Percentage of the $R \& D$ expenditures for Public Administrations, Universities, and private and public enterprises on the GDP. Measure calculated per year per region.

Number of graduates in science, technology, engineering and mathematics between 20 and 29 years old (per ISTAT thousand people).

\begin{tabular}{ll}
\hline University-level control variables & (all measures are per year per university) \\
& $\begin{array}{l}\text { Number of students, including Bachelor, Master, } \mathrm{PhD} \text { and } \\
\text { specialization courses (Logarithms are used in MIUR } \\
\text { University size } \\
\text { regressions). }\end{array}$
\end{tabular}

TTO size

Number of employees in TTOs.

CRUI

Regional-level control variables

Regional GDP growth

(all measures are per year per region)

Growth rate of regional gross domestic product.

ISTAT

Measurement of the income distribution of each region's residents. This number, which ranges between 0 and 1 and contributions (Logarithms are used in regressions). is based on residents' net income, helps define the gap between the rich and the poor, with 0 representing perfect equality and 1 representing perfect inequality.

Percentage of total employment employed in hi-tech manufacturing and knowledge intensive services.

ISTAT

Mean net household income, after taxes and mandatory

\section{ISTAT}

Hi-tech employment

Household income 
Italian level control variables

Consumer confidence index

Industry confidence index

Service confidence index

Final consumption expenditure (all measures are per year)

Economic indicator collected through a survey. Calculated per year at the Italian level.

EUROSTAT

Assessment of book order levels. Calculated per year at the Italian level.

EUROSTAT

Business situation development. Calculated per year at the Italian level.

EUROSTAT

Expenditure incurred by resident households on individual consumption of goods and services, including those sold at prices that are not economically significant, per

EUROSTAT inhabitant. (Logarithms are used in regressions). 
Table 3. Descriptive statistics. This table shows the descriptive statistics for the sample of 1,275 yearuniversity observations (85 universities, observed for 15 years from 1999 to 2013).

\begin{tabular}{|c|c|c|c|c|c|c|c|c|}
\hline & \multicolumn{2}{|c|}{ Italy } & \multicolumn{2}{|c|}{ North } & \multicolumn{2}{|c|}{ Centre } & \multicolumn{2}{|c|}{ South } \\
\hline & Mean & Std dev & Mean & $\overline{\text { Std dev }}$ & Mean & $\overline{\text { Std dev }}$ & Mean & Std dev \\
\hline Local unemployment (\%) & 8.71 & 5.36 & 4.89 & 1.60 & 7.30 & 2.23 & 15.90 & 4.34 \\
\hline Relative skilled unemployment & 0.97 & 0.14 & 0.99 & 0.12 & 0.98 & 0.16 & 0.93 & 0.14 \\
\hline Faculty research productivity & 0.82 & 0.74 & 0.98 & 1.02 & 0.77 & 0.55 & 0.63 & 0.24 \\
\hline Regional R\&D Expenditure (\%) & 1.10 & 0.39 & 1.21 & 0.32 & 1.14 & 0.44 & 0.75 & 0.27 \\
\hline STEM graduates & 10.6 & 4.6 & 12.2 & 3.9 & 12.1 & 4.5 & 6.4 & 2.6 \\
\hline University size (000s) & 31.2 & 27.5 & 30.3 & 32.3 & 32.9 & 27.3 & 30.8 & 23.2 \\
\hline TTO size (no) & 4.37 & 2.83 & 4.63 & 3.04 & 4.36 & 3.36 & 4.00 & 1.50 \\
\hline Regional GDP growth (\%) & 0.12 & 3.31 & 0.33 & 3.46 & 0.42 & 3.25 & -0.31 & 3.19 \\
\hline Gini Coefficient & 0.28 & 0.02 & 0.27 & 0.02 & 0.27 & 0.02 & 0.30 & 0.02 \\
\hline Hi-tech employment (\%) & 0.97 & 0.46 & 1.19 & 0.42 & 1.13 & 0.42 & 0.46 & 0.14 \\
\hline Household income $(000 €)$ & 15.87 & 3.18 & 18.50 & 1.23 & 16.34 & 1.74 & 11.50 & 1.14 \\
\hline Consumer confidence index & -17.98 & 8.39 & -17.98 & 8.39 & -17.98 & 8.39 & -17.98 & 8.39 \\
\hline Industry confidence index & -20.45 & 15.53 & -20.45 & 15.53 & -20.45 & 15.53 & -20.45 & 15.53 \\
\hline Service confidence index & -0.84 & 16.65 & -0.84 & 16.65 & -0.84 & 16.65 & -0.84 & 16.65 \\
\hline $\begin{array}{l}\text { Final consumption expenditure } \\
(000 €)\end{array}$ & 13.79 & 0.03 & 13.79 & 0.03 & 13.79 & 0.03 & 13.79 & 0.03 \\
\hline
\end{tabular}


Table 4. The role of local unemployment. This table reports the results of negative binomial panel regressions on the total number of spin-offs created, on the number of hi-tech spin-offs, and on the number of low-tech spin-offs per year by all Italian universities (excluding distance learning only institutions) over the period 1999-2013. Controls for the geographic area (North, Central, South) are included in all regressions. ***,**, and $*$ indicate significance at the 1,5 , and 10 percent levels, respectively.

\begin{tabular}{lccc} 
& Spin-offs & Hi-tech & Low-tech \\
\hline Local unemployment & $-0.310^{* * *}$ & $-0.312^{* * *}$ & $-0.568^{* * *}$ \\
Local unemployment ${ }^{2}$ & $(0.102)$ & $(0.102)$ & $(0.094)$ \\
& $0.008^{* *}$ & $0.008^{* *}$ & $0.017^{* * *}$ \\
Faculty research productivity & $(0.003)$ & $(0.003)$ & $(0.004)$ \\
& $0.483^{* *}$ & $0.448^{* *}$ & 0.066 \\
Regional R\&D Expenditure & $(0.226)$ & $(0.224)$ & $(0.320)$ \\
& $0.852^{* *}$ & $0.769^{*}$ & 0.368 \\
STEM graduates & $(0.402)$ & $(0.400)$ & $(0.586)$ \\
& $0.128^{* * *}$ & $0.122^{* * *}$ & $0.104 *$ \\
University size & $(0.036)$ & $(0.036)$ & $(0.063)$ \\
& $0.146^{* *}$ & $0.151^{* *}$ & $0.455^{* * *}$ \\
TTO size & $(0.078)$ & $(0.077)$ & $(0.171)$ \\
& $0.032^{* *}$ & $0.037 * *$ & $0.027 *$ \\
Regional GDP growth & $(0.017)$ & $(0.016)$ & $(0.017)$ \\
& -2.622 & -3.222 & -10.386 \\
Gini Coefficient & $(3.646)$ & $(3.672)$ & $(6.808)$ \\
Hi-tech employment & $-8.905^{*}$ & $-8.862^{*}$ & -17.538 \\
& $(5.275)$ & $(5.335)$ & $(15.878)$ \\
Household income & -0.420 & -0.435 & -0.202 \\
& $(0.296)$ & $(0.296)$ & $(0.411)$ \\
Consumer confidence index & -2.011 & -1.961 & $-3.808^{* *}$ \\
Industry confidence index & $(1.341)$ & $(1.335)$ & $(1.777)$ \\
Service confidence index & $0.055^{* * *}$ & $0.055^{* * *}$ & $0.094 * * *$ \\
& $(0.018)$ & $(0.018)$ & $(0.033)$ \\
Final consumption expenditure & 0.000 & 0.001 & 0.017 \\
Constant & $(0.009)$ & $(0.009)$ & $(0.015)$ \\
& 0.002 & 0.002 & 0.003 \\
Observations & $(0.008)$ & $(0.008)$ & $(0.015)$ \\
Log-likelihood & 0.142 & 0.143 & 0.322 \\
& $(0.146)$ & $(0.147)$ & $(0.262)$ \\
& 21.327 & 20.756 & $37.523 * *$ \\
& $(13.233)$ & $(13.226)$ & $(18.441)$ \\
\hline & 1,275 & 1,275 & 1,275 \\
& -795.7 & -780.9 & -297.1 \\
\hline
\end{tabular}


Table 5. The role of skilled unemployment. This table reports the results of negative binomial panel regressions on the total number of spin-offs created, on the number of hi-tech spin-offs, and on the number of low-tech spin-offs per year by all Italian universities (excluding distance learning only institutions) over the period 1999-2013. Controls for the geographic area (North, Central, South) are included in all regressions. $* * *, * *$, and $*$ indicate significance at the 1,5 , and 10 percent levels, respectively.

\begin{tabular}{lccc} 
& Spin-offs & Hi-tech & Low-tech \\
\hline Local unemployment & $-0.382^{* * *}$ & $-0.372^{* * *}$ & $-0.558^{* * *}$ \\
Local unemployment ${ }^{2}$ & $(0.108)$ & $(0.103)$ & $(0.094)$ \\
& $0.008^{* *}$ & $0.008^{* *}$ & $0.016^{* * *}$ \\
Skilled unemployment & $(0.003)$ & $(0.003)$ & $(0.004)$ \\
& $3.619^{* *}$ & $1.897 * *$ & 2.369 \\
Faculty research productivity & $(1.708)$ & $(0.479)$ & $(2.709)$ \\
& $0.571^{* *}$ & $0.486^{* *}$ & 0.077 \\
Regional R\&D Expenditure & $(0.239)$ & $(0.229)$ & $(0.324)$ \\
& $0.951^{* *}$ & $0.892^{* *}$ & 0.269 \\
STEM graduates & $(0.414)$ & $(0.407)$ & $(0.603)$ \\
& $0.156^{* * *}$ & $0.141^{* * *}$ & $0.117 *$ \\
University size & $(0.040)$ & $(0.037)$ & $(0.066)$ \\
& $0.116^{* *}$ & $0.131^{* *}$ & $0.458^{* * *}$ \\
TTO size & $(0.065)$ & $(0.062)$ & $(0.173)$ \\
& $0.041^{* *}$ & $0.043 * *$ & 0.028 \\
Regional GDP growth & $(0.020)$ & $(0.028)$ & $(0.020)$ \\
& -0.757 & -1.622 & -9.646 \\
Gini Coefficient & $(3.702)$ & $(3.669)$ & $(6.852)$ \\
Hi-tech employment & -8.376 & -6.974 & -16.004 \\
& $(5.354)$ & $(5.439)$ & $(16.091)$ \\
Household income & -0.436 & -0.368 & -0.154 \\
& $(0.304)$ & $(0.300)$ & $(0.416)$ \\
Consumer confidence index & $-3.195 * *$ & $-3.197 * *$ & $-4.113^{* *}$ \\
Industry confidence index & $(1.494)$ & $(1.412)$ & $(1.828)$ \\
Service confidence index & $0.061^{* * *}$ & $0.052^{* * *}$ & $0.094^{* * *}$ \\
Final consumption expenditure & $(0.018)$ & $(0.018)$ & $(0.033)$ \\
Constant & -0.003 & -0.001 & 0.016 \\
& $(0.009)$ & $(0.009)$ & $(0.015)$ \\
Observations & -0.001 & -0.005 & 0.002 \\
Log-likelihood & $(0.008)$ & $(0.008)$ & $(0.015)$ \\
& 0.109 & 0.085 & 0.317 \\
& $(0.146)$ & $(0.147)$ & $(0.263)$ \\
& $36.756^{* *}$ & $34.689 * *$ & $42.291 * *$ \\
& $(15.529)$ & $(14.028)$ & $(19.461)$ \\
\hline & 1,275 & 1,275 & 1,275 \\
& -793.7 & -775.1 & -296.7 \\
\hline & & & \\
& & & \\
& & &
\end{tabular}


Table 6. Moderators of skilled unemployment. This table reports the results of negative binomial panel regressions on the number of Hi-tech spin-offs created per year by all Italian universities (excluding distance learning only institutions) over the period 1999-2013. Controls for the geographic area (North, Central, South) are included in all regressions. ***,**, and * indicate significance at the 1,5 , and 10 percent levels, respectively.

\begin{tabular}{|c|c|c|c|}
\hline & (1) & $(2)$ & (3) \\
\hline \multirow{2}{*}{ Local unemployment } & $-0.378 * * *$ & $-0.363 * * *$ & $-0.393 * * *$ \\
\hline & (0.109) & $(0.112)$ & $(0.111)$ \\
\hline \multirow[t]{2}{*}{ Local unemployment ${ }^{2}$} & $0.008^{* *}$ & $0.007 * *$ & $0.009 * *$ \\
\hline & $(0.003)$ & $(0.004)$ & $(0.003)$ \\
\hline \multirow[t]{2}{*}{ Skilled unemployment } & $1.979 * * *$ & $2.077 * * *$ & $1.961 * * *$ \\
\hline & $(0.597)$ & $(0.511)$ & $(0.449)$ \\
\hline \multirow{2}{*}{$\begin{array}{l}\text { Skilled unemployment } x \\
\text { Faculty research productivity }\end{array}$} & $0.210^{* * *}$ & & \\
\hline & $(0.079)$ & & \\
\hline \multirow{2}{*}{$\begin{array}{l}\text { Skilled unemployment } \times \\
\text { Regional R\&D expenditure }\end{array}$} & & $1.590 *$ & \\
\hline & & $(0.902)$ & \\
\hline \multirow[t]{2}{*}{$\begin{array}{l}\text { Skilled unemployment } \times \\
\text { STEM graduates }\end{array}$} & & & $0.615 * *$ \\
\hline & & & $(0.282)$ \\
\hline \multirow[t]{2}{*}{ Faculty research productivity } & $0.370 * * *$ & $0.462 * *$ & $0.470^{* *}$ \\
\hline & $(0.151)$ & $(0.232)$ & $(0.227)$ \\
\hline \multirow{2}{*}{ Regional R\&D Expenditure } & $1.061 * * *$ & 0.494 & $0.825 * *$ \\
\hline & $(0.397)$ & (0.444) & $(0.406)$ \\
\hline \multirow[t]{2}{*}{ STEM graduates } & $0.138 * * *$ & $0.141 * * *$ & 0.085 \\
\hline & $(0.037)$ & $(0.038)$ & $(0.190)$ \\
\hline \multirow[t]{2}{*}{ University size } & 0.142 & 0.139 & 0.133 \\
\hline & $(0.131)$ & $(0.131)$ & $(0.131)$ \\
\hline \multirow[t]{2}{*}{ TTO size } & 0.037 & 0.039 & 0.047 \\
\hline & $(0.046)$ & $(0.046)$ & $(0.047)$ \\
\hline \multirow[t]{2}{*}{ Regional GDP growth } & -3.358 & -3.021 & -1.221 \\
\hline & (3.684) & $(3.748)$ & (3.759) \\
\hline \multirow[t]{2}{*}{ Gini Coefficient } & -8.252 & -7.185 & -6.621 \\
\hline & $(5.443)$ & $(5.425)$ & $(5.450)$ \\
\hline \multirow[t]{2}{*}{ Hi-tech employment } & -0.278 & -0.245 & -0.363 \\
\hline & $(0.292)$ & $(0.291)$ & $(0.300)$ \\
\hline \multirow[t]{2}{*}{ Household income } & -1.582 & -2.081 & -3.373 \\
\hline & $(1.323)$ & $(1.387)$ & $(2.517)$ \\
\hline \multirow[t]{2}{*}{ Consumer confidence index } & $0.040 * *$ & $0.041^{* *}$ & $0.055^{* * *}$ \\
\hline & $(0.017)$ & $(0.017)$ & $(0.018)$ \\
\hline \multirow[t]{2}{*}{ Industry confidence index } & 0.003 & 0.004 & -0.001 \\
\hline & $(0.008)$ & $(0.008)$ & $(0.009)$ \\
\hline \multirow[t]{2}{*}{ Service confidence index } & -0.003 & -0.006 & -0.004 \\
\hline & $(0.008)$ & $(0.009)$ & $(0.009)$ \\
\hline \multirow[t]{2}{*}{ Final consumption expenditure } & 0.138 & 0.114 & 0.089 \\
\hline & $(0.148)$ & $(0.149)$ & $(0.148)$ \\
\hline \multirow[t]{2}{*}{ Constant } & 17.505 & $23.224 *$ & $35.252 * *$ \\
\hline & $(13.166)$ & $(13.706)$ & $(15.324)$ \\
\hline & 1,275 & 1,275 & 1,275 \\
\hline Log-likelihood & -775.4 & -777.9 & -778.5 \\
\hline
\end{tabular}


Appendix. Correlation matrix. This table shows the correlation matrix for the variables used in the empirical analysis. * indicates significance at 5 percent level.

\begin{tabular}{|c|c|c|c|c|c|c|c|c|c|c|c|c|c|c|c|c|c|c|}
\hline & & 1 & 2 & 3 & 4 & 5 & 6 & 7 & $8 \mathrm{a}$ & 9 & 10 & 11 & 12 & 13 & $14 \mathrm{a}$ & 15 & 16 & 17 \\
\hline 1 & Spin-offs & 1.000 & & & & & & & & & & & & & & & & \\
\hline 2 & Hi-tech spin-offs & $0.991 *$ & 1.000 & & & & & & & & & & & & & & & \\
\hline 3 & Low-tech spin-offs & $0.637 *$ & $0.644 *$ & 1.000 & & & & & & & & & & & & & & \\
\hline 4 & Local unemployment & $-0.132 *$ & $-0.128 *$ & $-0.110^{*}$ & 1.000 & & & & & & & & & & & & & \\
\hline 5 & Relative skilled unemployment & $0.064 *$ & $0.061 *$ & 0.043 & $-0.438^{*}$ & 1.000 & & & & & & & & & & & & \\
\hline 6 & Faculty research productivity & 0.033 & 0.032 & 0.030 & $-0.134 *$ & 0.060 & 1.000 & & & & & & & & & & & \\
\hline 7 & Regional R\&D Expenditure & 0.052 & 0.055 & $0.090 *$ & $-0.317 *$ & 0.006 & $0.153 *$ & 1.000 & & & & & & & & & & \\
\hline 8 & STEM graduates & $0.225 *$ & $0.223 *$ & $0.158^{*}$ & $-0.483^{*}$ & $0.233 *$ & $0.287 *$ & $0.609 *$ & 1.000 & & & & & & & & & \\
\hline 9 & University size & $0.118 *$ & $0.121 *$ & $0.085^{*}$ & $0.106^{*}$ & -0.018 & $-0.423 *$ & $0.079 *$ & -0.017 & 1.000 & & & & & & & & \\
\hline 10 & TTO size & $0.072 *$ & $0.083 *$ & 0.041 & $-0.092 *$ & -0.011 & $0.106 *$ & $0.093^{*}$ & $0.068 *$ & $0.085^{*}$ & 1.000 & & & & & & & \\
\hline 11 & Regional GDP growth & 0.047 & 0.040 & 0.026 & $-0.110^{*}$ & $0.202 *$ & -0.006 & -0.010 & $0.105^{*}$ & 0.021 & 0.005 & 1.000 & & & & & & \\
\hline 12 & Gini Coefficient & $-0.153 *$ & $-0.150 *$ & $-0.119 *$ & $0.653 *$ & $-0.273^{*}$ & $-0.227 *$ & $0.109 *$ & $-0.338 *$ & $0.253^{*}$ & -0.060 & -0.050 & 1.000 & & & & & \\
\hline 13 & Hi-tech employment & 0.034 & 0.031 & $0.082 *$ & $-0.557^{*}$ & $0.215^{*}$ & 0.009 & $0.527 *$ & $0.476^{*}$ & 0.052 & $0.157 *$ & 0.025 & $-0.182 *$ & 1.000 & & & & \\
\hline 14 & Household income & $0.168^{*}$ & $0.166^{*}$ & $0.153^{*}$ & $-0.824 *$ & $0.186^{*}$ & $0.225 *$ & $0.548 *$ & $0.742 *$ & -0.045 & $0.139^{*}$ & 0.049 & $-0.537 *$ & $0.620 *$ & 1.000 & & & \\
\hline 15 & Consumer confidence index & $-0.174 *$ & $-0.173 *$ & $-0.120^{*}$ & -0.001 & $-0.259^{*}$ & $-0.265^{*}$ & $-0.149 *$ & $-0.531 *$ & -0.004 & 0.000 & 0.029 & $0.212 *$ & -0.055 & $-0.215^{*}$ & 1.000 & & \\
\hline 16 & Industry confidence index & -0.057 & -0.061 & -0.027 & $-0.066^{*}$ & $-0.196^{*}$ & $-0.190 *$ & $-0.132 *$ & $-0.308^{*}$ & 0.010 & 0.000 & $0.509^{*}$ & $0.116^{*}$ & -0.041 & $-0.093^{*}$ & $0.592 *$ & 1.000 & \\
\hline 17 & Service confidence index & $-0.103 *$ & $-0.103 *$ & $-0.072 *$ & -0.020 & $-0.340^{*}$ & $-0.181 *$ & $-0.114 *$ & $-0.385 *$ & -0.007 & 0.000 & $0.255^{*}$ & $0.105 *$ & -0.032 & $-0.122 *$ & $0.685^{*}$ & $0.782 *$ & 1.000 \\
\hline 18 & Final consumption expenditure & $0.258 *$ & $0.257 *$ & $0.171^{*}$ & $-0.261 *$ & $0.347 *$ & $0.079 *$ & $0.124 *$ & $0.460 *$ & 0.034 & 0.000 & $0.316^{*}$ & $-0.244 *$ & $0.120 *$ & $0.209 *$ & $-0.482 *$ & $-0.165 *$ & $-0.244 *$ \\
\hline
\end{tabular}

